GLOBAL JOURNAL OF GEOLOGICAL SCIENCES VOL. 15, 2017: 1-11 COPYRIGHTC BACHUDO SCIENCE CO. LTD PRINTED IN NIGERIA ISSN 1596-6798

www.globaljournalseries.com, Email: info@globaljournalseries.com

\title{
MINERALOGICAL AND GEOCHEMICAL TRENDS IN LATERITIC WEATHERING PROFILES ON BASEMENT ROCKS IN AWA-ORU IJEBU AND ITS ENVIRON, SOUTHWESTERN NIGERIA
}

A. J. ADEOLA AND R. G. DADA

(Received 14 March 2016; Revision Accepted 14 June 2016)

\begin{abstract}
Three soil profiles on the basement rocks in Awa-Oru-ljebu Igbo area of southwestern Nigeria were investigated for the formation secondary minerals and the comparison of the mineralogical and geochemical patterns in the weathering profiles overlying the rocks during the humid tropical weathering.

X-ray data showed that the primary mineral constituents of the rocks such as feldspar, biotite, hornblende have altered to kaolinite and hematite. In soil horizon, kaolinite and quartz are the dominant minerals. The concentration of hematite in the laterite indicated that most of the iron oxides generated in the soil horizon have been leached into the underlying laterite layer. Kaolinite is the dominant mineral in the clayey horizon and its presence suggests that some of the iron bearing ferromagnesian minerals have altered into the kaolinite.

Geochemical data further revealed significant enrichment of $\mathrm{Al}_{2} \mathrm{O}_{3}$ and $\mathrm{Fe}_{2} \mathrm{O}_{3}$ in the laterite profile compared with the parent rock, while, $\mathrm{CaO}, \mathrm{Na}_{2} \mathrm{O}, \mathrm{K} 2 \mathrm{O}, \mathrm{P}_{2} \mathrm{O}_{5}$ and $\mathrm{MnO}$ show strong depletion up the profiles. The removal of mobile elements by meteoric water and subsequent concentration of stable weathering products results in lateritization. The absence of bauxite minerals like gibbsite and diaspora in the profiles shows that the trend of weathering is towards iron enrichment (ferralitization) and not aluminum accumulation (bauxitization). The CIA values of the lateritic layers shows that the weathering process is matured and has reached advanced stage.
\end{abstract}

KEYWORDS: Basement rocks, weathering, lateritization, kaolinite, Hematite.

\section{INTRODUCTION}

Laterites and lateritic soils abound in tropical and subtropical regions of the world. They are largely products of intense physico- chemical decomposition of rocks under hot and humid climatic conditions. On tropical African shields, lateritization processes have led to the development of weathering mantles ten of meter thick often capped with ferricretes at the expense of all kinds of parent rocks that may reflect a long and complex evolution including climatic geomorphological changes (Aleva 1994). Such lateritization processes commonly involve preferential leaching and concentration of valuable deposits, such as ores of aluminium, iron, nickel, chromium, cobalt, manganese, gold, tin, niobium and tantalum. Other minerals include bauxites, phosphate, industrial clays and gemstones. The clayey residues generated from the chemical decomposition of rocks within these areas are sometimes found to be suitable for industrial applications.

In the south western Nigeria, extensive occurrences of such residual bodies have been reported by various workers (Kehinde-Phillip 1991, Elueze and Bolarinwa 1994, Emofurieta et al 1994, Bolarinwa 2001, Ige et al., 2005, Bolarinwa 2006, Adegbuyi et al., 2015). Profile investigation reveals erratic variation in the major oxide composition and pronounced dissimulation in mineralogical characteristics in line with the parent rock and chemical environments. Hence, translocation and redistribution of the weathering products through groundwater and percolating rain water under appropriate Eh and pH conditions (Norton, 1973), result in lateritization or duricrust formation. Thick lateritic deposits overly and blanket bedrock in most part of Nigeria (Durotoye and Malomo, 1982). The studying of the removal of mobile elements by meteoric water from the well established crystalline rocks, the resulted chemical variation along the profile and subsequent concentration of stable weathering products is the focus of present investigation.

\section{Geologic Setting}

The study area, Oru-Awa-ljebu-lgbo and its environs, lie within the Basement Complex of south western Nigeria. It forms part of the Pan African mobile belt which lies to the east of West African Craton. Hence, several authors have worked on and classified the basement rocks based on their association and geochronology. Some of the classifications were carried out by Jones and Hockey (1964), Oyawoye (1972) and Oyinloye 2007. Rahaman (1976) classified the basement complex rock units into 5 different groups viz: the migmatite - gneiss - quartzite complex, The newer metasediments, Chanockite, diorite and gabbro, Older granite, Unmetamorphosed acid and basic intrusive and hyperbyssal rocks. 


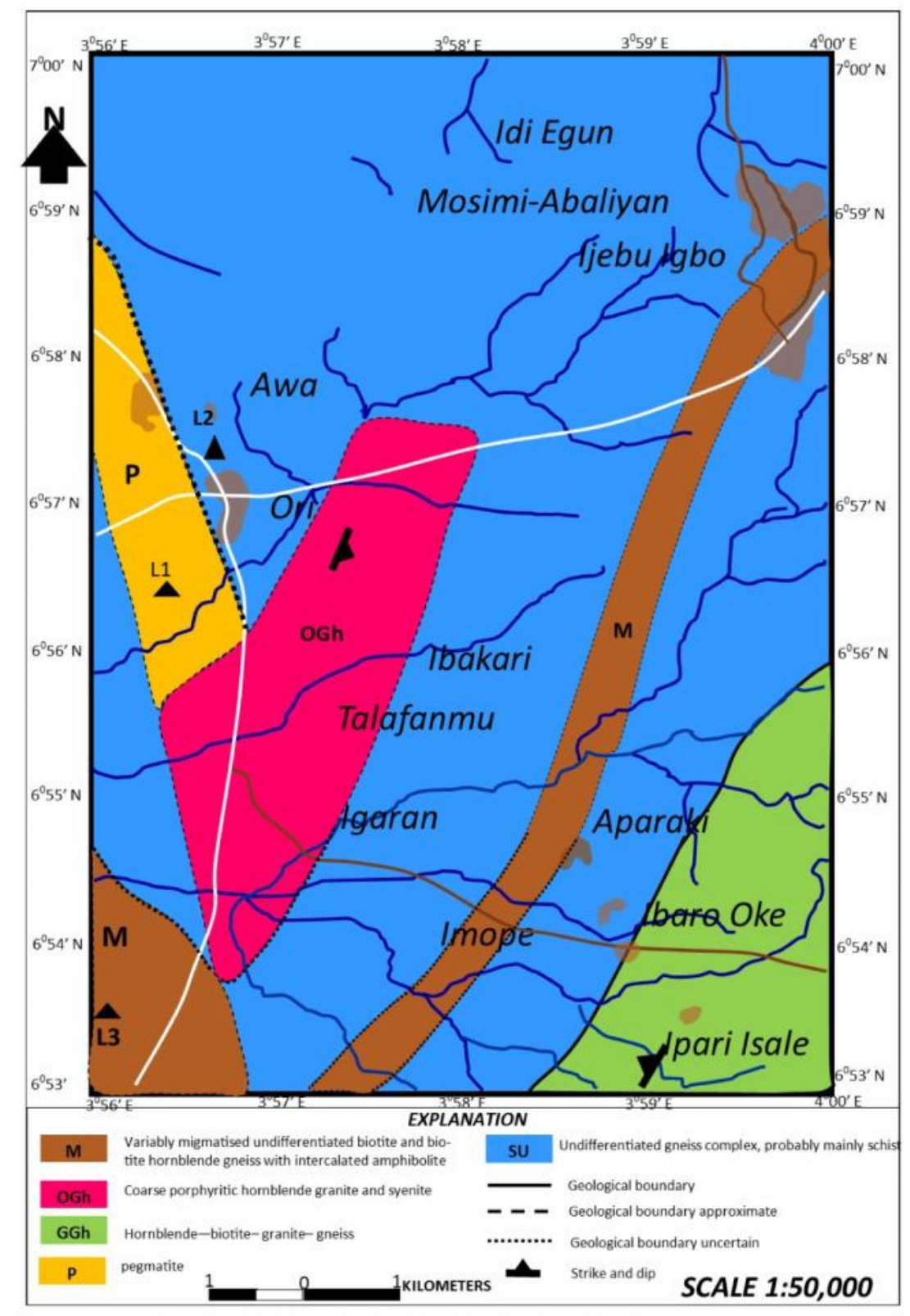

Fig.1: Geologic Map of Awa-Oru ljebu Igbo and its environs showing the profile locations (Modified after Nigeria Geological Survey Agency, Abuja 2004)

The major rock types in the area of study include granite gneiss, granite, pegmatite and undifferentiated migmatite and these have been intruded by quartz veins and pegmatite veins. (Fig.1). Granite gneiss stretches from the eastern part to the north west of the area. Generally, it is grey in colour and texturally medium grained. Mineralogically, it consists of quartz, plagioclase, feldspar, biotite and hornblende. Granite is the second abundant rock type in the area covering the entire eastern and northwestern region. The colour is grey and texturally medium grained. Mineralogically, banded gneiss contains both felsic and mafic minerals. The felsic minerals consist of feldspar and quartz while the mafic mineral consists of biotite and hornblende and other accessory minerals. Pegmatite is located at the western part of area of study. The entire Oru Township is underlain by pink pegmatite. Texturally, it ranges from medium to coarse grained. Mineralogically, feldspar and quartz are the most abundant minerals while muscovite and tourmaline occurs as accessory mineral. Muscovite flakes from the weathered pegmatite liter the immediate surrounding and tourmaline grains released from the weathered can be equally picked up in the soil. 


\section{MATERIAL AND METHODS}

Samples of rocks, clay, laterite and soil were obtained from fresh road cuts at specified intervals from top soil down to fresh basement rocks at Oru, Oru-ljebu Ode and ljebu-lgbo. Sixty samples comprising 15 each of top-soil, laterite, clay and rock were collected from three lateritic profiles above pegmatite, granite gneiss and granite. Petrographic study was carried out in twelve thin sections of the rock samples. Clay mineralogy was determined using X-ray Diffraction (XRD) at Activation Laboratory in Canada. The X-ray diffraction analysis was performed on a Panalytical X'Pert Pro diffractometer, equipped with a Cu X-ray source and an X'celerator detector, operating at the following conditions: voltage: $40 \mathrm{kV}$; current: $40 \mathrm{~mA}$; range: $5-80$ deg $2 \theta$; step size: 0.017 deg $2 \theta$; time per step: $50.165 \mathrm{sec}$; divergence slit: fixed, angle $0.5^{\circ}$. The crystalline mineral phases were identified in X'Pert High Score Plus using the PDF-4 Minerals 2013 ICDD database. The quantities of the crystalline minerals were determined using the Rietveld method. The Rietveld method is based on the calculation of the full diffraction pattern from crystal structure information. The X-ray power diffraction patterns were obtained using a Siemens. Elemental compositions of the rocks and clay samples were determined using Inductively Coupled Plasma-Mass Spectrometer (ICP-MS). For ICP-MS, microwave high pressure/temperature decomposition of samples (230o C, 7.0Mpa; Paar Physical Multiwave sample preparation system) using Merck Suprapurs grade reagents $(\mathrm{HF}, \mathrm{HClO} 4, \mathrm{HNO} 3$ and $\mathrm{HCl}$ ). All measurements were made on a Sciex/Perkin-Elmer ELAR 6000 ICP-MS. Chemical Index of Alteration (CIA) was calculated from the elemental data to determine the intensity of weathering.

\section{RESULTS AND DISCUSSION}

Weathering Profiles above pegmatite, granite gneiss and granite at Awa-Oru area

Profile 1 is $4 \mathrm{~m}$ thick exposed along Oru-ljebuIgbo road, at Oru-Awa junction on pegmatite (Fig.2). Profile 2 is a fresh road cut about $3.5 \mathrm{~m}$ in thickness, encountered about $4.5 \mathrm{~km}$ along ljebu-Ode road, while Profile 3 is a $3.9 \mathrm{~m}$ thick profile exposed along ljebu-lgbo road above granite, at the north eastern part of the study area. The weathering profiles over pegmatite, granite gneiss and granite are residual because, on the field, there is no evidence of movement of the soil except for the local down slope wash that characterized the base of the profiles above. Based on colour, texture, and relic structures, four distinct layers consisting of top soil, laterite, clayey and parent rock horizons were identified on the pegmatite and granite while granite gneiss has only three layers. The clay horizon is conspicuously absent from the profile on granite gneiss (Fig. 2)

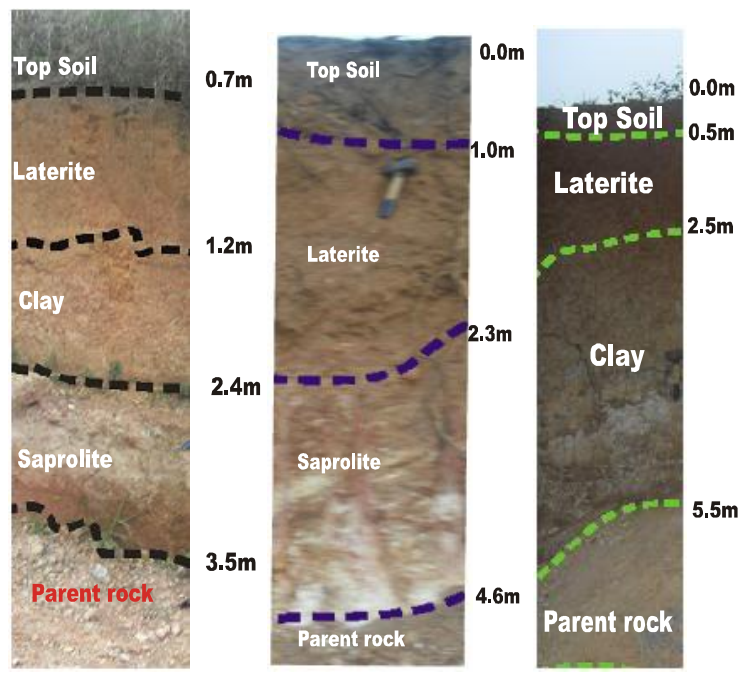

Fig.2: Weathering profiles above basement rocks

$\mathbf{a}=$ Pegmatite profile at Oru, $\quad \mathbf{b}=$ granite gneiss profile Oru- ljebu Ode, $\mathbf{c}=$ granite profile at ljebu-lgbo

The upper horizon which is the top soil on pegmatite is generally light brownish in colour and ranged between $0.2 \mathrm{~m}$ to $1.1 \mathrm{~m}$ in thickness. This layer contains pebbles of quartz as a result of leaching and some organic matter in the form of plant rootlets and decomposed leaves, below this horizon is brownish and partly consolidated laterite. The thickness of the lateritic layer ranged between 0.5 to $3.5 \mathrm{~m}$ and grades gradually into the underlying clay horizon. The clay zone characterized by some whitish and reddish spots consist of quartz and kaolinite. The red spots are mainly iron oxides. However, kaolinite is derived from the decomposition of feldspar while the iron rich spots are formed as a result of the decomposition of ferromagnesian mineral such as biotite that is present in the primary rock. The contact between the clay horizon and the bedrock is sharp. 

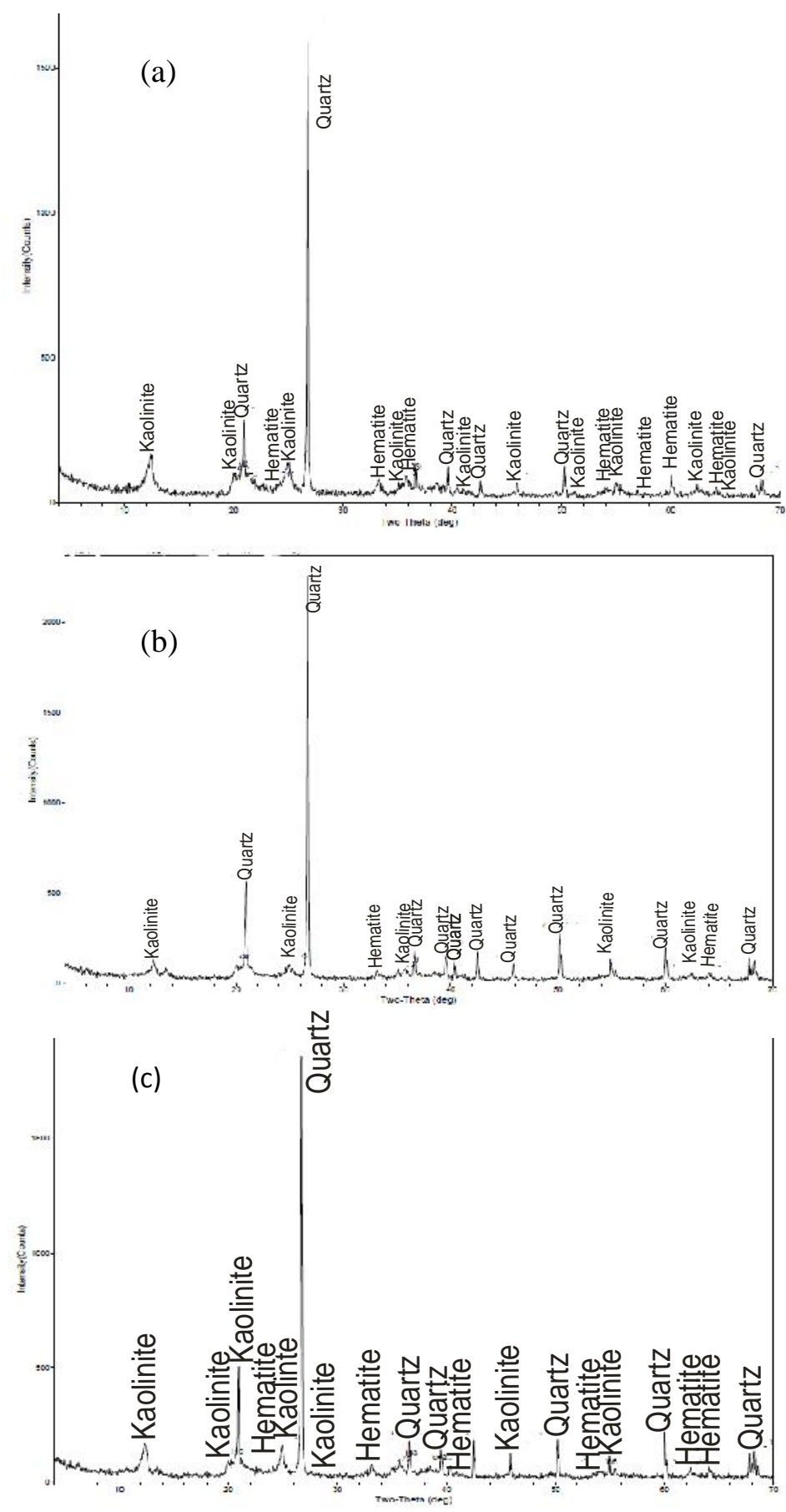

Fig. 3: X-ray diffractogram of the weathered profile above pegmatite at Oru (a) = soil $\quad$ (b) $=$ laterite $\quad(\mathbf{c})=$ clay

The $X$ ray charts of soil samples (Fig. 3) on pegmatite exhibits similar mineral assemblages to laterite and clay. Prominent peaks of kaolinite, quartz and hematite are recorded in both top soil and laterite while kaolinite and quartz dominate the peaks of clay and hematite. The $X$ - ray diffractograms of soil and laterite layers on the granite gneiss are shown in Fig. 4. The $X$ ray charts of soil and laterite show similarity in their mineralogical compositions. The peaks of albite and quartz are prominently recorded in both soil and laterite horizons. There is predominance of albite over iron-oxides. Hence, iron -oxides concentrated in laterite indicating that most of the iron oxides generated in the soil horizon have not been leached into underlying laterite layer. The X-ray diffractograms of soil, laterite and clay layers on the granite are shown in Fig.5. The prominent peaks of kaolinite and quartz are recorded in the X-ray diffractograms o of soil and laterite and clay displays the presence of kaolinite, quartz and Albite (Fig. 5c). 

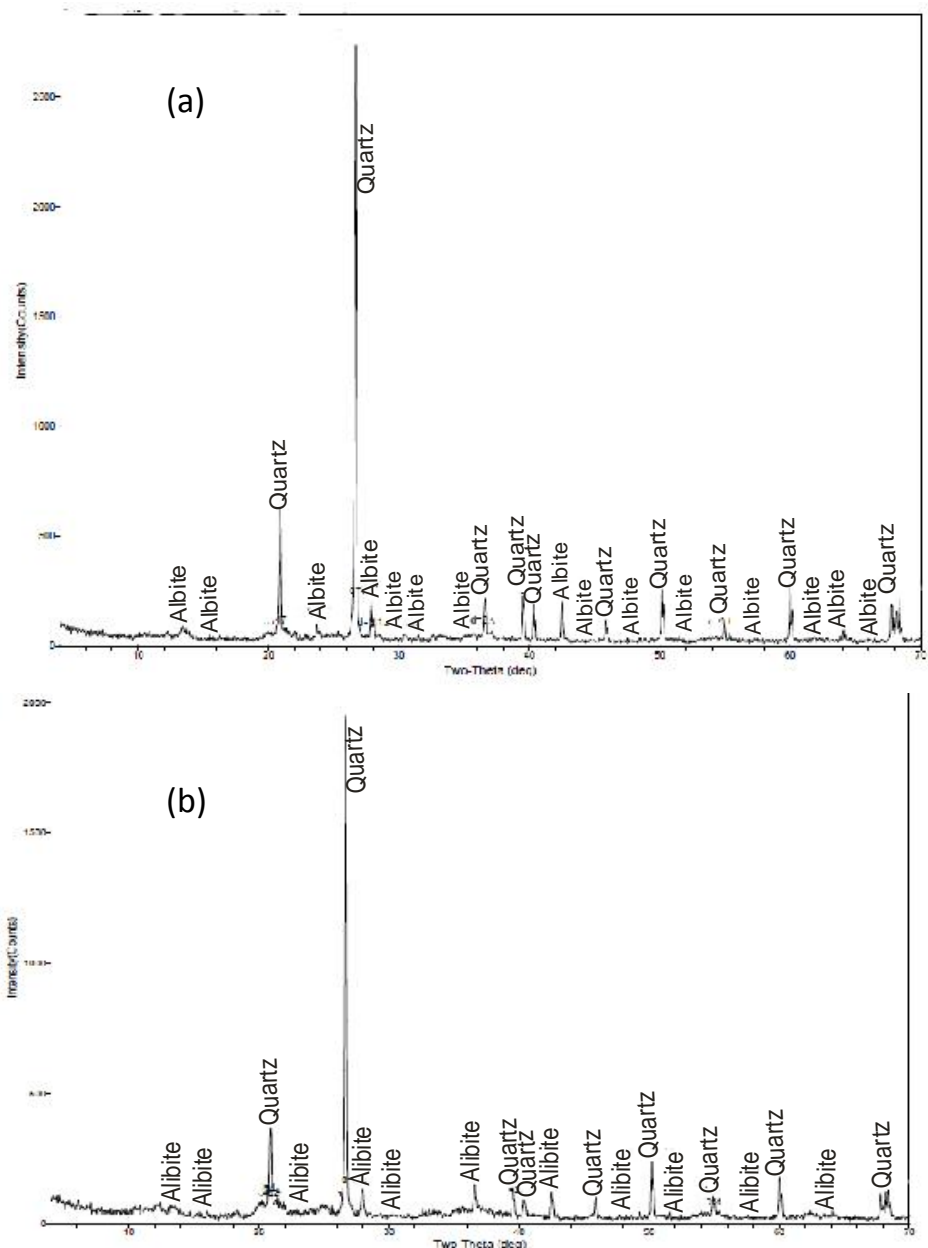

Fig. 4: X-RD diffractogram of soil layer above granite gneiss along Oru-ljebu-Ode road (a) = soil $\quad(b)=$ laterite 

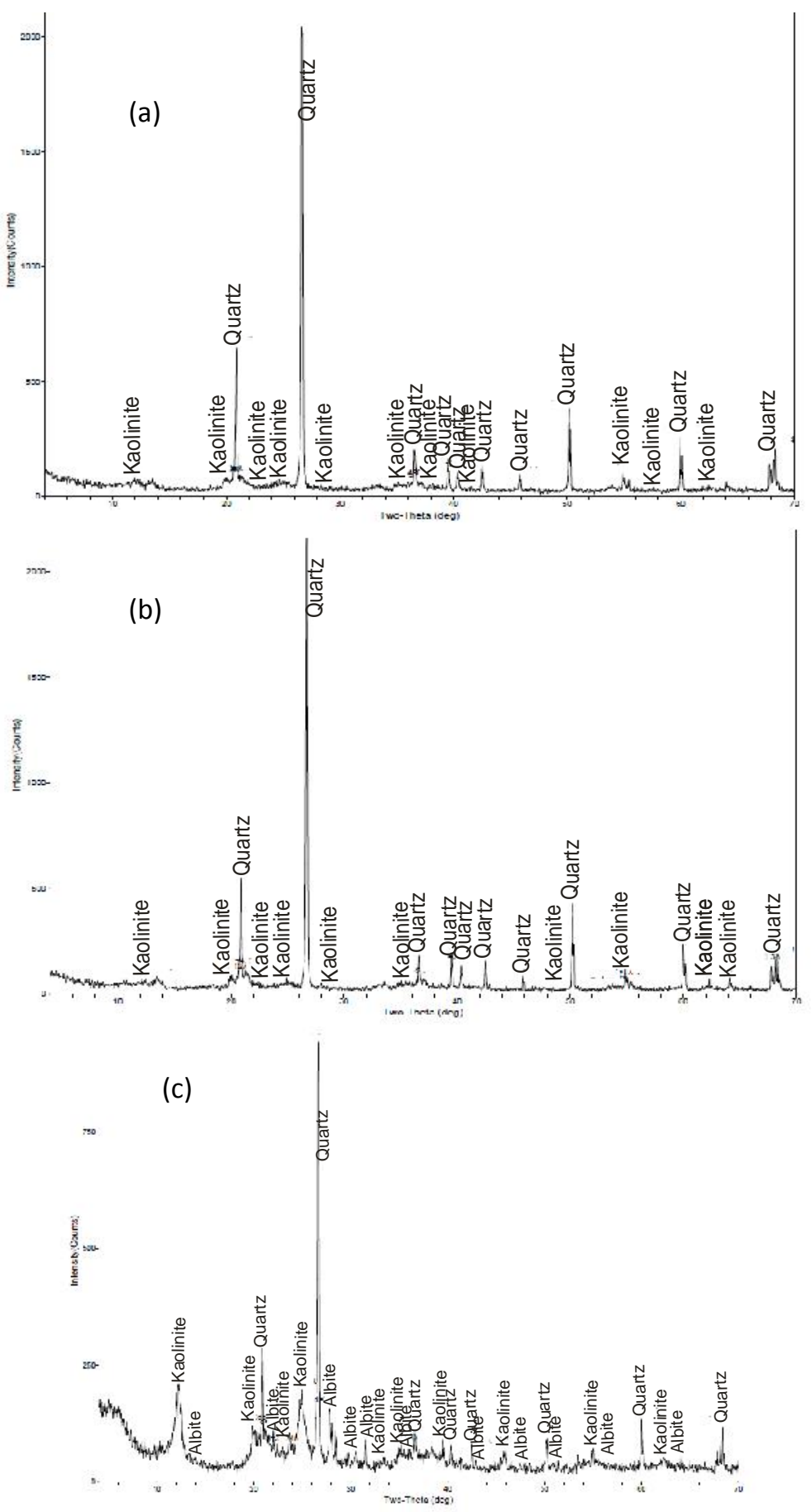

Fig. 5: X-RD diffractogram of weathering profile above granite in ljebu-Igbo
(a) $=$ soil
(b) = laterite
(c) = clay

In soil and laterite horizons, kaolinite predominate over iron oxides. However, iron oxides concentration in the laterite is higher that its values in other horizons indicating that most of the iron oxides generated in the soil horizon have been leached into the underlying laterite layer. Kaolinite is the dominant mineral in the clayey horizon as indicated by the high intensity of its numerous peaks in the $X$ ray diffractogram. The presence of kaolinite also suggests that some of the iron bearing ferromagnesian minerals have been altered into the kaolinite.

\section{Geochemistry of the study area:}

a) Major elements

The average concentrations of major and trace elements in the weathering profile over pegmatite at Oru town are presented in Table (1). The mean compositions of $\mathrm{SiO}_{2}$ are $70.63 \%, 60.11 \%, 51.48 \%$ and $64.07 \%$ in the parent rock, clay, laterite and soil respectively. This 
shows that relative to the parent rock, there has been depletion in the $\mathrm{SiO}_{2}$ in the weathering profile. The enhanced value of $64.07 \%$ in the top soil may be due to relative depletion of $\mathrm{MnO}, \mathrm{MgO}, \mathrm{CaO}, \mathrm{Na}_{2} \mathrm{O}, \mathrm{K}_{2} \mathrm{O}$, in the horizon. Hence, apart from the occurrence of free quartz, $\mathrm{SiO}_{2}$ is present in silicate minerals such as biotite and hornblende. The weathering and dissolution of these silicate minerals apparently led to the enrichment of $\mathrm{SiO}_{2}$ and $\mathrm{Fe}_{2} \mathrm{O}_{3}$ (t) in the top soil. The average concentration values of $\mathrm{Al}_{2} \mathrm{O}_{3}$ increase from $14.41 \%$ in the parent rock to $20.20 \%$ in the clay with $24.24 \%$ in laterite. This indicates that there is a significant enrichment of $\mathrm{Al}_{2} \mathrm{O}_{3}$ in the clay and laterite profile compared to the parent rock. From the chemical data, the relative enrichment could be explained by the removal of $\mathrm{MgO}$ and weathering of $\mathrm{Al}_{2} \mathrm{O}_{3}$ bearing minerals such as biotite in the pegmatite. $\mathrm{Fe}_{2} \mathrm{O}_{3}$ has average of $1.4 \%, 10.44 \%, 12.61 \%$ and $9.35 \%$ in the parent rock, clay, laterite and soil respectively. This indicates strong enrichment $\mathrm{Fe}_{2} \mathrm{O}_{3}$ in the weathering profile relative to the parent rock (Fig. 6). This is typical of the weathering and lateritization of granitic rocks. The value of the average $\mathrm{Fe}_{2} \mathrm{O}_{3}$ concentration show that the iron bearing minerals such as biotite and hornblende etc in the parent rock have probably been affected by chemical weathering to release iron oxides/hydroxide in the horizons.

Table 1: Average chemical composition of major (\%) and trace element (ppm) over pegmatite

\begin{tabular}{|c|c|c|c|c|c|c|c|c|}
\hline Oxides & $\begin{array}{l}\text { Rock } \\
\text { Mean }\end{array}$ & Range & $\begin{array}{l}\text { Clay } \\
\text { Mean }\end{array}$ & Range & $\begin{array}{l}\text { Laterite } \\
\text { Mean }\end{array}$ & Range & $\begin{array}{l}\text { Top soil } \\
\text { Mean }\end{array}$ & Range \\
\hline \multicolumn{9}{|c|}{$70.70 .10-71.16$} \\
\hline $\mathrm{SiO}_{2}$ & 63 & & 60.11 & $59.63-60.90$ & 51.48 & $51.22-51.83$ & 64.07 & $63.67-64.41$ \\
\hline $\mathrm{Al}_{2} \mathrm{O}_{3}$ & 14.41 & $14.41-14.46$ & 20.20 & $20.2-20.26$ & 24.24 & $24.03-24.36$ & 17.06 & $17-17.09$ \\
\hline $\mathrm{Fe}^{2} \mathrm{O}_{3}$ & 1.4 & $1.25-1.56$ & 10.44 & $9.88-10.93$ & 12.61 & $12.08-12.61$ & 9.35 & $9.14-9.67$ \\
\hline $\mathrm{MgO}$ & 0.40 & $0.37-0.44$ & 0.06 & $0.06-0.06$ & 0.13 & $0.12-0.13$ & 0.14 & $0.13-0.14$ \\
\hline $\mathrm{CaO}$ & 1.61 & $1.56-1.66$ & 0.03 & $0.03-0.03$ & 0.03 & $0.03-0.04$ & 0.12 & $0.12-0.12$ \\
\hline $\mathrm{Na}_{2} \mathrm{O}$ & 3.15 & $3.14-3.17$ & 0.03 & $0.02-0.04$ & 0.02 & $0.01-0.03$ & 0.05 & $0.04-0.05$ \\
\hline $\mathrm{K}_{2} \mathrm{O}$ & 5.70 & $5.63-5.73$ & 0.14 & $0.13-0.14$ & 0.26 & $0.25-0.27$ & 0.25 & $0.25-0.26$ \\
\hline $\mathrm{TiO}_{2}$ & 0.11 & $0.09-0.14$ & 0.87 & $0.86-0.88$ & 1.03 & $1.03-1.04$ & 1.16 & $1.15-1.17$ \\
\hline $\mathrm{P}_{2} \mathrm{O}_{5}$ & 0.11 & $0.08-0.15$ & 0.03 & $0.01-0.04$ & 0.04 & $0.03-0.05$ & 0.06 & $0.05-0.06$ \\
\hline $\mathrm{MnO}$ & 0.02 & $0.01-0.02$ & 0.02 & $0.02-0.02$ & 0.03 & $0.03-0.03$ & 0.06 & $0.06-0.06$ \\
\hline LOI & 0.67 & $0.63-0.71$ & 8.00 & 7.89 & 7.76 & 7.88 & 8.00 & 9.92 \\
\hline Total & & & 99.86 & & 99.83 & & 99.85 & \\
\hline \multicolumn{9}{|c|}{ Trace Element (ppm) } \\
\hline & 3192 & 3083-3302 & & & & & & \\
\hline $\mathrm{Ba}$ & & & 84 & $80-87$ & 157 & $154-164$ & 131 & $124-136$ \\
\hline $\mathrm{Sr}$ & $\begin{array}{l}609 \\
7\end{array}$ & $\begin{array}{l}596-623 \\
3-10\end{array}$ & 7 & $6-9$ & 15 & $14-17$ & 17 & $16-18$ \\
\hline $\mathrm{Zr}$ & & & 165 & $152-178$ & 171 & $158-176$ & 282 & $258-322$ \\
\hline Y & 8 & $6-9$ & 15 & $14-17$ & 17 & $15-21$ & 20 & $18-22$ \\
\hline $\mathrm{Nb}$ & & & 7 & $5-9$ & 13 & $5-17$ & 30 & $17-43$ \\
\hline Sc & 1 & $1-1$ & 13 & $13-14$ & 16 & $16-17$ & 14 & $14-15$ \\
\hline \multicolumn{9}{|c|}{ Silica - Aluminum Ratio } \\
\hline SR & 6.32 & $6.18-6.45$ & 1.96 & $1.916-2.03$ & 1.40 & $1.38-1.42$ & 2.43 & $2.38-2.46$ \\
\hline AR & $\begin{array}{l}10.4 \\
8.86\end{array}$ & $\begin{array}{l}9.26-11.54 \\
8.82-8.9\end{array}$ & 1.94 & $1.848-2.039$ & 1.92 & $1.83-2.02$ & 1.83 & $1.85-1.77$ \\
\hline $\mathrm{MgO}+$ & & & 0.09 & $0.09-0.09$ & 0.16 & $0.16-0.16$ & 0.26 & $0.25-0.26$ \\
\hline $\mathrm{Na}_{2} \mathrm{O}+$ & 2.01 & $1.93-2.1$ & 0.16 & $0.16-0.17$ & 0.28 & $0.3-0.27$ & 0.30 & $0.30-0.31$ \\
\hline
\end{tabular}

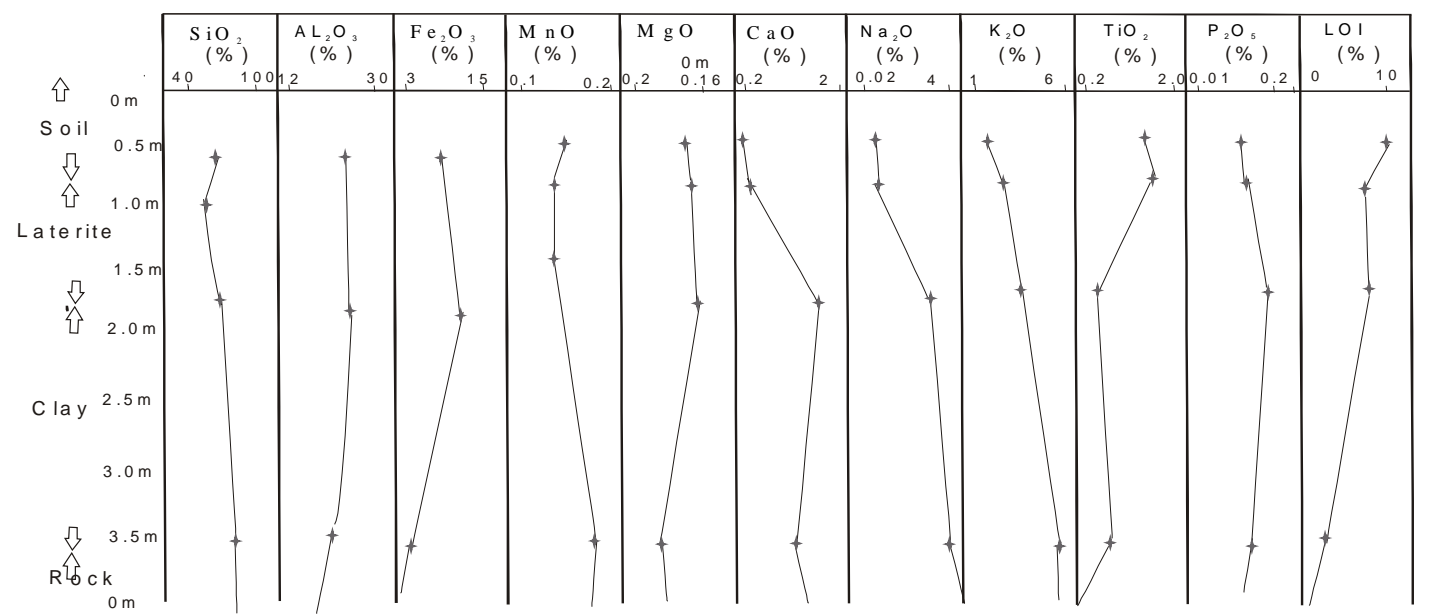

Fig. 6: Chemical variation along weathered profile above pegmatite at Awa 
The average concentrations of major and trace elements in the weathering profile over granite at ljebuOde are presented in Table 2. The mean compositions of $\mathrm{SiO}_{2}$ are $68.86 \%, 59.75 \%$ and $73.04 \%$ in the parent rock, laterite and soil respectively. However, this shows that relative to the parent rock, there has been depletion in the $\mathrm{SiO}_{2}$ in the weathering profile. The enhanced value of $73.04 \%$ in the top soil may be due to the occurrence of free quartz. The weathering and dissolution of these silicate minerals in granite apparently led to the enrichment of $\mathrm{SiO}_{2}$ and $\mathrm{Fe}_{2} \mathrm{O}_{3}$ (t) in the top soil. The average concentration values of $\mathrm{Al}_{2} \mathrm{O}_{3}$ increase from $15.08 \%$ in the parent rock to $17.06 \%$ in laterite and reduce to $10.35 \%$ in the top soil. This indicates that there is a significant enrichment of $\mathrm{Al}_{2} \mathrm{O}_{3}$ in the laterite profile compared to the parent rock (Fig. 7). From the chemical data, the relative enrichment could be explained by the removal of $\mathrm{MgO}$ and weathering of $\mathrm{Al}_{2} \mathrm{O}_{3}$ bearing minerals such as biotite in the granite. $\mathrm{Fe}_{2} \mathrm{O}_{3}$ has average of $3.3 \%, 11.87 \%$ and $7.80 \%$ in the parent rock, laterite and soil respectively. This indicates strong enrichment $\mathrm{Fe}_{2} \mathrm{O}_{3}$ in the weathering profile relative to the parent rock. This is typical of the weathering and lateritization of felsic rocks. The weathering trend is similar to that of pegmatite.

Table 2: Average chemical composition of major (\%) and traces element (ppm) over granite gneiss along Oru-ljebu-Ode

\begin{tabular}{|c|c|c|c|c|c|c|}
\hline & Rock & & Laterit & & Top soi & \\
\hline Oxides & Mean & Range & Mean & Range & Mean & Range \\
\hline $\mathrm{SiO}_{2}$ & 68.86 & $68.05-69.44$ & 59.75 & $59.29-60.56$ & 73.04 & $72.82-73.31$ \\
\hline $\mathrm{Al}_{2} \mathrm{O}_{3}$ & 15.08 & $14.89-15.08$ & 17.06 & $16.7-17.53$ & 10.35 & $10.27-10.44$ \\
\hline $\mathrm{Fe}_{2} \mathrm{O}_{3}$ & 3.30 & $2.76-3.79$ & 11.87 & $10.53-12.82$ & 7.80 & $7.55-7.76$ \\
\hline $\mathrm{MgO}$ & 1.07 & $0.73-1.53$ & 0.42 & $0.41-0.43$ & 0.27 & $0.26-0.27$ \\
\hline $\mathrm{CaO}$ & 3.38 & 3.13- 3.67 & 0.69 & $0.65-0.72$ & 1.00 & $1.00-1.01$ \\
\hline $\mathrm{Na}_{2} \mathrm{O}$ & 4.30 & $4.07-4.45$ & 0.47 & $0.5-0.48$ & 0.79 & $0.78-0.8$ \\
\hline $\mathrm{K}_{2} \mathrm{O}$ & 1.75 & $1.27-2.05$ & 0.21 & $0.2-0.22$ & 0.18 & $0.17-0.18$ \\
\hline $\mathrm{TiO}_{2}$ & 0.42 & $0.31-0.40$ & 1.35 & $1.29-1.41$ & 1.36 & $1.35-1.37$ \\
\hline $\mathrm{P}_{2} \mathrm{O} 5$ & 0.12 & $0.11-0.14$ & 0.09 & $0.08-0.11$ & 0.08 & $0.07-0.08$ \\
\hline $\mathrm{MnO}$ & 0.05 & $0.03-0.07$ & 0.15 & $0.14-0.16$ & 0.23 & $0.21-0.24$ \\
\hline LOI & 0.37 & $0.36-0.38$ & 4.65 & 4.51 & 4.54 & 4.57 \\
\hline TOTAL & & & 99.82 & $99.81-99.84$ & 99.86 & $99.84-99.87$ \\
\hline Trace Eleme & ppm) & & & & & \\
\hline $\mathrm{Ba}$ & 916 & $622-1130$ & 151 & $175-196$ & 277.33 & $256-296$ \\
\hline $\mathrm{Sr}$ & 704 & $665-780$ & 245 & $78-87$ & 130.67 & $130-131$ \\
\hline $\mathrm{Zr}$ & 151 & $136-163$ & 374 & $525-571$ & 986.67 & $904-1039$ \\
\hline Y & 5.3 & $4-7$ & 21 & $9-11$ & 12 & $11-12$ \\
\hline $\mathrm{Nb}$ & & & 28 & $28-43$ & 28 & $21-36$ \\
\hline Sc & 5 & $3-7$ & 8 & $11-12$ & 7 & $6-7$ \\
\hline Silica - Alum & m Ratio & & & & & \\
\hline SR & 7.84 & $7.42-8.21$ & 2.07 & $2.008-2.158$ & 4.02 & $3.951-4.114$ \\
\hline$A R$ & 4.63 & $4.06-5.39$ & 1.45 & $1.303-1.665$ & 1.33 & $1.36-1.281$ \\
\hline $\mathrm{MgO}+\mathrm{CaO}$ & 6.06 & $5.34-6.45$ & 1.11 & $1.06-1.14$ & 1.27 & $1.27-1.27$ \\
\hline $\mathrm{Na}_{2} \mathrm{O}+\mathrm{K}_{2} \mathrm{O}$ & 4.45 & $3.86-4.29$ & 0.69 & $0.7-0.72$ & 1.24 & $0.95-1.79$ \\
\hline CIA & 61.52 & $56.82-62.9$ & 92.56 & $92.41-92.83$ & 81.62 & $80.15-83.91$ \\
\hline
\end{tabular}

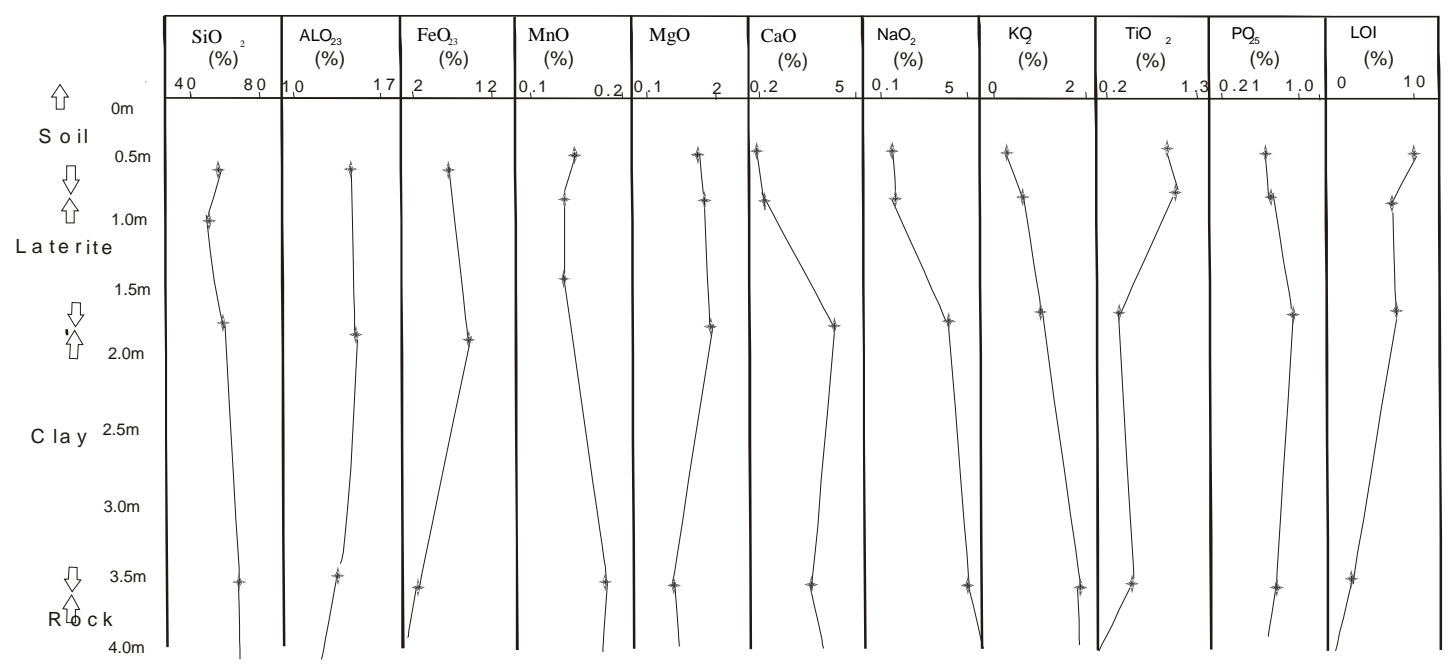

Fig. 7: Chemical variation along weathered profile above granite gneiss at Oru-ljebu Ode road 
The average concentrations of major and trace elements in the weathering profile over granite along ljebu-lgbo road are presented in Table (3). The weathering trend in all the oxides is similar to that of

granite and pegmatite (Fig.

Table 3: Average chemical composition of major (\%) and trace elements (ppm) over granite at ljebu-lgbo

\begin{tabular}{|c|c|c|c|c|c|c|c|c|}
\hline Oxides & $\begin{array}{l}\text { Rock } \\
\text { Mean }\end{array}$ & Range & $\begin{array}{l}\text { Clay } \\
\text { Mean }\end{array}$ & Range & $\begin{array}{l}\text { Laterite } \\
\text { Mean }\end{array}$ & Range & $\begin{array}{l}\text { Top soil } \\
\text { Mean }\end{array}$ & Range \\
\hline $\mathrm{SiO}_{2}$ & 68.49 & $67.23-69.75$ & 55.39 & $55.15-55.61$ & 64.45 & $63.2-65.39$ & 71.55 & $70.72-72.13$ \\
\hline $\mathrm{Al}_{2} \mathrm{O}_{3}$ & 15.35 & $14.99-15.17$ & 22.62 & $22.57-22.66$ & 12.99 & $12.88-13.07$ & 12.48 & $12.19-12.68$ \\
\hline $\mathrm{Fe}_{2} \mathrm{O}_{3}$ & 2.85 & $2.56-3.14$ & 9.40 & $9.27-9.67$ & 14.10 & $13.07-15.25$ & 8.30 & $7.92-8.84$ \\
\hline $\mathrm{MgO}$ & 1.18 & $1.02-1.34$ & 0.64 & $0.58-0.65$ & 0.16 & $0.16-0.17$ & 0.16 & $0.15-0.16$ \\
\hline $\mathrm{CaO}$ & 4.34 & $3.98-4.71$ & 0.98 & $0.93-1.01$ & 0.21 & $0.20-0.21$ & 0.25 & $0.23-0.26$ \\
\hline $\mathrm{Na}_{2} \mathrm{O}$ & 4.95 & $4.72-5.18$ & 0.62 & $0.56-0.65$ & 0.10 & $0.10-0.09$ & 0.12 & $0.10-0.13$ \\
\hline $\mathrm{K}_{2} \mathrm{O}$ & 1.31 & $0.19-1.72$ & 0.18 & $0.20-0.18$ & 0.13 & $0.12-0.13$ & 0.17 & $0.16-0.18$ \\
\hline $\mathrm{TiO}_{2}$ & 0.20 & $0.17-0.23$ & 1.14 & $1.14-1.14$ & 0.88 & $0.87-0.89$ & 0.83 & $0.82-0.84$ \\
\hline $\mathrm{P}_{2} \mathrm{O}_{5}$ & 0.14 & $0.12-0.17$ & 0.02 & $0.02-0.02$ & 0.06 & $0.06-0.06$ & 0.05 & $0.04-0.06$ \\
\hline $\mathrm{MnO}$ & 0.05 & $0.05-0.06$ & 0.03 & $0.03-0.03$ & 0.08 & $0.05-0.11$ & 0.06 & $0.06-0.06$ \\
\hline LOI & 0.50 & $0.50-0.51$ & 8.72 & $8.84-8.73$ & 6.60 & $6.53-6.72$ & 5.83 & $5.70-5.81$ \\
\hline Total & & & 99.83 & & 99.84 & & 99.88 & \\
\hline \multicolumn{9}{|c|}{ Trace element (ppm) } \\
\hline $\mathrm{Ba}$ & 610.5 & $229-992$ & 168.67 & $141-187$ & 103.67 & $70-154$ & 83.33 & $72-94$ \\
\hline $\mathrm{Sr}$ & 719.5 & $719-720$ & 147 & $139-151$ & 32.67 & $32-33$ & 38.67 & $36-40$ \\
\hline $\mathrm{Zr}$ & 107 & $104-110$ & 249 & $219-296$ & 381.00 & $362-417$ & 368.00 & $333-386$ \\
\hline $\bar{Y}$ & 19 & $17-21$ & 9 & $8-9$ & 9 & $8-10$ & 5 & $4-5$ \\
\hline $\mathrm{Nb}$ & 10 & $9-13$ & 33 & $28-38$ & 44.67 & $33-51$ & 36.67 & $30-40$ \\
\hline Sc & 13 & $11-15$ & 14 & $14-15$ & 8 & $8-9$ & 7 & $7-8$ \\
\hline \multicolumn{9}{|c|}{ Silica - Aluminum Ratio } \\
\hline SR & 7.31 & $7.21-7.41$ & 0.29 & $0.30-0.29$ & 0.42 & $0.40-0.447$ & 0.58 & $0.59-0.58$ \\
\hline$A R$ & 5.42 & $5.0-5.82$ & 1.51 & $1.43-1.59$ & 0.93 & $0.85-1.00$ & 2.41 & $2.34-2.44$ \\
\hline $\mathrm{MgO}+\mathrm{CaO}$ & 6.26 & $6.09-6.44$ & 0.40 & $0.39-0.41$ & 0.37 & $0.37-0.37$ & 1.62 & $1.51-1.68$ \\
\hline $\mathrm{Na}_{2} \mathrm{O}+\mathrm{K}_{2} \mathrm{O}$ & 5.52 & $5-6.05$ & 0.29 & $0.26-0.31$ & 0.22 & $0.21-0.23$ & 0.80 & $0.72-0.85$ \\
\hline
\end{tabular}

CIA

$59.15 \quad 56.89-59.62$

92.70

$92.52-92.83$

96.65

96.28-96.95

95.85

$95.61-96.69$

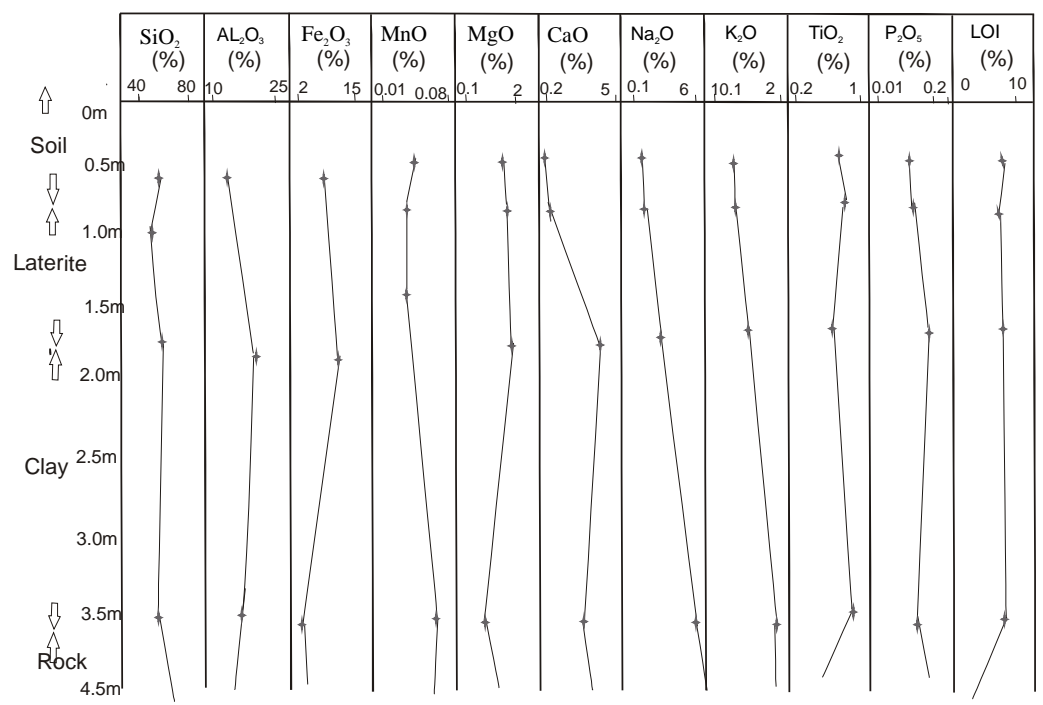

Fig. 8: Chemical variation along weathered profile above granite at ljebu Igbo

Loss of concentration of the oxides as typified in granite, the depletion of $\mathrm{CaO}, \mathrm{Na}_{2} \mathrm{O}, \mathrm{K}_{2} \mathrm{O}, \mathrm{P}_{2} \mathrm{O}_{5}$, and $\mathrm{MnO}$ are particularly pronounced and they are removed at a faster rate. The corresponding values for $\mathrm{CaO}$ are $0.06 \%, 0.13 \%$ and $0.14 \% 4.34 \%, 0.98 \%, 0.25 \%, 0.21 \%$, $\mathrm{Na}_{2} \mathrm{O}$ are $4.95 \% 0.62 \% 0.10 \% 0.12 \% \mathrm{~K}_{2} \mathrm{O}$ are $1.31 \%$ $0.18 \% \quad 0.13 \% \quad 0.17 \%, \mathrm{P}_{2} \mathrm{O}_{5}$ are $0.14 \% \quad 0.02 \% \quad 0.06 \%$ $0.05 \%, \mathrm{MnO}$ are $0.05 \% 20.03 \% 0.08 \% 0.06 \%$, LOI are $0.50 \%, 8.72 \%, 6.60 \%, 5.83 \%$ in the rock, clay, laterite and soil respectively indicate leaching from the parent rock up the profile. This progressive dissolutions and mobility of magnesium, calcium, potassium, sodium has led to their depletions in the weathering profiles (Kehinde - Philips 1995, Bolarinwa 2001). According to Aleva 1994, the decrease in $\mathrm{CaO}, \mathrm{Na}_{2} \mathrm{O}, \mathrm{K}_{2} \mathrm{O}, \mathrm{P}_{2} \mathrm{O}_{5}$, and $\mathrm{MnO}$ contents of the weathering profiles relative to the parent rock is due to leaching of these oxides.

\section{b) Trace element}

Trace elements data in Tables 1, 2 and 3 show enhancement of $Z r$ in clay, laterite and soil compared to the parent rock, $\mathrm{Zr}$ increased from 107 to 249.33ppm in 
clay then increased to $381.00 \mathrm{ppm}$ in laterite and decreased to $368.00 \mathrm{ppm}$ in soil, however, Ba depleted from 610.5 to $168.67 \mathrm{ppm}$ in clay and further decreased to $103.67 \mathrm{ppm}$ and $83.33 \mathrm{ppm}$ in laterite and soil respectively. Sr depleted from 729.5 to $147.00 \mathrm{ppm}$ in clay then decrease to $32.67 \mathrm{ppm}$ in laterite and also slightly increased to $38.67 \mathrm{ppm}$ in soil, $Y$ depleted from 19 to $8.67 \mathrm{ppm}$ in clay then decreased to $8.67 \mathrm{ppm}$ in laterite. Sc increased from 13 to $14.33 \mathrm{ppm}$ in clay then decrease to $8.33 \mathrm{ppm}$ in laterite and depleted to $7.00 \mathrm{ppm}$ in the soil.

The silica sequioxide ratios (S.R) of granite are: rock (7.31), clay $(0.29)$, laterite $(0.42)$, soil $(0.58)$ (Table 3). The alumina-iron (A.R) are (5.42), (1.51), (0.93), (2.41) for rock, clay, laterite and soil. However, silicasequioxide ratio (S.R) of pegmatite are $6.32,1.40$ and 2.32), and granite gneiss S.R. 7.84, 2.07 and 4.2 in rock, laterite and soil respectively. The relatively high S.R and A.R strongly suggest that true laterites are produced from the weathering of iron bearing minerals in the pegmatite (Aleva, 1994). The total values of alkalis $(\mathrm{MgO}+\mathrm{CaO})$ are 6.26 in the rock and $0.40,0.37$ and 1.62 in the clay, laterite and soil respectively while the total values of $\left(\mathrm{Na}_{2} \mathrm{O}+\mathrm{K}_{2} \mathrm{O}\right)$ is 5.52 in the rock, 0.29 , 0.22 and 0.80 in clay, laterite and soil. The relatively high $\mathrm{Na}_{2} \mathrm{O}+\mathrm{K}_{2} \mathrm{O}$ are mainly contributed by the weathered plagioclase feldspars and muscovite minerals while high $\mathrm{MgO}$ and $\mathrm{CaO}$ is probably due to the low mount of mafic minerals in the parent rock. The silicasequioxide ratio has been used to quantify the degree of weathering and lateritization (Martins and Doyne, 1927).

According to Nesbitt and Young (1984), When $\mathrm{CIA}$ values range from 30 to 55 ; it is an indication of weathering at incipient zone, while CIA values ranging from 51 to 85 could be considered as intermediate zone of weathering. Weathering that is at the advanced stage will have CIA values greater than 85 . Fresh and unaltered granitic rocks will have $\mathrm{CIA}$ values around 50 and plot along plagioclase-K-feldspar or slightly below as shown in the A-CN- K diagram (Fig. 9), because of breakdown of plagioclase feldspar during the initial stages of weathering. $\mathrm{Ca}$ and $\mathrm{Na}$ are removed from the weathered rocks and $\mathrm{Al}_{2} \mathrm{O}_{3}$ is increased, as the residual clay mineral is retained in the weathered profile. A residual soil rich in clay minerals such as kaolinite would have a CIA value close to 100 . Therefore, the position of sample of weathered products of rocks or soil in the A$\mathrm{CN}$ - $\mathrm{K}$ diagram as well as its $\mathrm{CIA}$ value would be a good indicator of the extent of chemical weathering experienced by the rock (Nesbitt and Young, 1984, Anuspam and Rajamani, 2000).Table 1, 2 and 3 show the summary of the average values of the calculated Chemical Index of Alterations (CIA) for the different weathering profiles in Awa-Oru area. According to the $\mathrm{CIA}$ values of all the samples in Awa-Oru area showed increasing trends of weathering that have reached the advanced stage. The average CIA values of pegmatite are 57.94, 98.73 and 97.60 , granite gneiss are 61.52, 92.56 and 81.62 and granite are57.15, 96.65, 95.85 for rock, laterite and soil respectively. The clay CIA values in both pegmatite and granite are 99.03 and 92.70 . Based on the CIA values recorded in Table 1, 2 and 3, it is observed that pegmatite has experienced high intensity of chemical weathering the values also indicate progressive chemical weathering that has reached matured stage with high intensity.

\section{CONCLUSIONS}

The lateritic profiles above pegmatite, granite gneiss and granite in Awa-Oru ljebu Igbo and its environs are structurally related to the overlying weathering profiles. The mineralogy of the parent rocks greatly influenced and determined the textural characteristics and colour variation within and between profiles. The weathering profile over pegmatite and granite can be distinguished into top soil, iron rich laterite, clay and bedrock. The essential rock forming minerals in the basement rocks, such as feldspar, biotite, hornblende, have been chemically decomposed to clay minerals such as kaolinite. Hematite is the nonclay components, derived essentially from the lateritization of iron-bearing minerals such as biotite and hornblende,

Close examinations of the whole rock geochemical data reveal that only $\mathrm{Fe}_{2} \mathrm{O}_{3}, \mathrm{Al}_{2} \mathrm{O}_{3}$ and $\mathrm{TiO}_{2}$ are relatively enriched in lateritic profiles above the basement rock. The other oxides, notably $\mathrm{SiO}_{2}, \mathrm{MnO}$, $\mathrm{MgO}, \mathrm{CaO}, \mathrm{Na}_{2} \mathrm{O}, \mathrm{K}_{2} \mathrm{O}$, and $\mathrm{P}_{2} \mathrm{O}_{5}$ are depleted due to leaching. Studies of major element distribution shows relative enhancement of $\mathrm{Al}_{2} \mathrm{O}_{3}$ in the clayey zone and $\mathrm{Fe}_{2} \mathrm{O}_{3}$ in the laterized zone above pegmatite, granite gneiss and granite. These enrichments are reflected as kaolinite and hematite peaks in the relevant $x$-ray diffractograms. This shows that the weathering is towards lateritization than bauxitization. Among the three lithologies, pegmatite exhibits the highest degree of weathering.

\section{ACKNOWLEDGEMENT}

The authors acknowledge the contributions of our colleagues in the Department of Geology and Mineral Sciences, Crawford University, Igbesa, Ogun State.

\section{REFERENCES}

Adegbuyi, O., Ojo, G. P., Adeola, A. J and Alebiosu, M. T., 2015. Compositional and industrial assessment of Isua Akoko, Akure. Ayadi and Ode Aye clay deposits of Ondo State, Nigeria. Global Journal of Pure and SApplied Sciences. 21, 38-46.

Aleva, G. J., 1994. Laterites; Concepts, Geology, Morphology and Chemistry, ISRIC, Wageningen. 169.

Anupam, S and Rajamani, V., 2000. Weathering of gneissic rocks in the upper reaches of Cauvery river, south India: implications to neotectonics of the region. Chemical Geology, 166, 203-223.

Bolarinwa, A. T., 2001. Compositional characteristics and economic potentials of the lateritic profiles over basement and sedimentary rocks in Ibadan-Abeokuta area, southwestern Nigeria, Unpublished Ph.D. Thesis, University of Ibadan. 255. 
Bolarinwa, A. T., 2006. Mineralogy and geochemistry of the weathering profiles above basement rocks in Ibadan, southwestern, Nigeria. Global Journal of Geological Sciences, 4, (2): 183-191.

Elueze, A. A and Bolarinwa, A. T., 1994. Assessment of function, application of lateritic clay bodies in Ekiti environs, south western Nigeria Journal of Mining and Geology, 31, 79-83.

Emofurieta, W. O., Ogundimu. T. O and Imeokparia, E. G., 1994. Mineralogical, Geochemical and Economic Appraisal of some clay and shale deposits in Southwestern and northeastern Nigeria. Jour. Mineral. Geol. 30, (2): 151-159.

Durotoye, B. and Malomo, S., 1982. The problem of the undefined "laterites" in nigeria jour. Min. Geol. $19,310-312$.

Ige, O. A., Durotoye, B and Oluyemi, A. E., 2005. Mineralogy and geochemistry of lateritic weathering profiles on ultramafic rock bodies around Mokuro in Ile-Ife area, southwestern Nigeria. Journal of Mining and Geology, 41, (1): 11-18.

Jones, H. A and Hockey, R. D., 1964. The geology of part of Southwestern Nigeria. Geol. Surv. Nigeria Bull. 31, 101.

Kehinde-Phillips, O. O., 1991. Compositional variations within laterite profiles over mafic and ultramafic rock units of the llesha schist belt, Southwestern Nigeria PhD. Thesis university of Ibadan, Unpubl 201.

Kehinde-Phillips, O. O and Tietz, G. F., 1995. The mineralogy and geochemistry of the weathering profiles over amphibollite and Talk-schists in the llesha scist belt, southwestern Nigeria Journal of Mining and Geology, Vol. 31, No. 1 pp 53-62.
Martins, F. J and Doyne, F. C., 1927. Laterite and lateritic soils in Sierra Leone; Int. Jour, Agric sci. $17,530-55$.

Nesbitt, H. W and Young, G. M., 1984. Prediction of some weathering trends of plutonic and volcanic rocks based on thermodynamic and kinetic. Geochim. Cosmochin. Acta, 48. 1523-1534.

Norton, S. A., 1973. Laterite and bauxite formation. Economic Geology, 68,

Ola, S. A., 1982. Geotechnical properties and behavior of some Nigeria lateritic soils. Tropical soils of Nigeia in Engineering Practice. Ola S.A. (Ed) 61-63.

Oyawoye, M. O., 1972. The geology of the Nigerian Basement Complex. Journ. Nigerian Min. Ceol. And Metall. Soc.

Oyinloye, O. A., 2007. Geology and geochemistry of some crystalline besement rocks in llesha area, southwestern Nigeria: Implications on provenance and evolution. Pakistan Journal of Scientific and Industrial Research, 50, (4): 233231.

Rahaman, M. A., 1976. Review of the basement geology of Southwestern Nigeria in C.A.Kogbe (Editor) geology of Nigeria, Elizabeth publications Lagos, 41-58. 
